\title{
複合材タンクロ元部接着構造におけるエネルギ解放率低減化手法の考察*1 Contribution of Reduction Method for Energy Release Rate of Adhesive Bonding Structure in Composite Tank around Mouthpiece
}

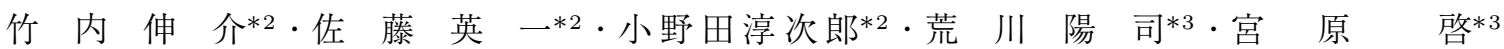 \\ Shinsuke Takeuchi, Eiichi Sato, Junjiro Onoda, Yoji Arakawa and Akira MiYahara
}

Key Words : Composite Tank, Bonding Structure, Fracture Mechanics, Energy Release Rate

\begin{abstract}
This paper includes evaluations of composite tanks or pressure vessels based on fracture mechanics and an improved method for tank design. Problems of exfoliation between the mouthpiece and composite in current composite pressure vessels are shown, and the simple solution by inducing a slit into the mouthpiece near the bonding interface is proposed. The effect of the slit is evaluated using a geometrically simple model as well as a pressure vessel model designed for a rocket.
\end{abstract}

\section{記 号 表}

*': 添字'は亀裂進展後の值を示す

$*_{\mathrm{P}}$ : 添字 $\mathrm{P}_{\mathrm{P}}$ は圧力による值を示す

$E:$ ヤン゙率

$\mathrm{ERR}:$ エネルギ解放率

$J:$ スリットがある時のエネルギ解放率

$J_{0}:$ スリットがない時のエネルギ解放率

$L_{0}:$ 予亀裂長さ

$M:$ 曲げ膜モーメント

$T:$ 楕円球殼の膜力

$l:$ スリット深さ

$t:$ スリット〜予亀裂間距離

$W:$ スリット幅

$\epsilon:$ 弾性歪

$\kappa:$ 曲率（曲げ曲率半径の逆数）

\section{1. 研 究 背 景}

軽量な複合材容器は, 航空宇宙分野においては従来の金 属製推進剂タンクあるいは気蓄器の代替手段として期待さ れており，文献 1〜4) には筆者らのグループで進められて いる複合材液体水素タンクの研究成果が示されている。 ケットの極低温推進剂タンクに関しては当初は米国 DC-X, X-33 等でも開発が進められていたが, 漏洩等の問題5,6) か ら現在国外では開発中止となっている。一方で現行のロケッ 卜や圧縮天然ガス $(\mathrm{CNG})$ 自動車, 将来の水素自動車・燃 料電池自動車等の気蓄器や燃料タンクとして, 常温・高圧 の圧力容器の研究も進められている7). 特に CNG タンクに

\footnotetext{
*1 (C) 2010 日本航空宇宙学会

平成 22 年 4 月 21 日原稿受付

*2 宇宙航空研究開発機構宇宙科学研究所

*3 富士重工業（株）
}

ついては，既に世界各国で車両用として様々な商品が開発 され自動車に搭載されている(一例としては米国 Lincoln Composites 社の HP ${ }^{8)}$ 等を参照).

複合材タンクの使用に当たっては，現在の技術では外部 配管との接続部でのシールの問題から，通常金属製の口金 が使用されている。このため複合材タンクでは異種材料間 の接着が必要となり, 条件によりこの接着部の剝離が設計 評定となる場合がある，特に極低温のタンクにおいては，勒 性の低下によりこの接着部が破壊力学的な設計評定となる 場合が多(9).

対して常温のタンク・気蓄器等では, 文献 7) に示される ように, 現在の所複合材の応力・歪など通常の強度評定を 用いて設計を行い, 疲労については繰り返し加圧試験等で 確認を行うことが多いようである。しかし文献9)では常温 における口金端部のエネルギ解放率はほぼ内圧の自乗に比 例して増加することが示されている。これはエネルギ解放 率を求める下式に扮いて,

$$
\mathrm{ERR}_{\mathrm{P}}=\frac{1}{2} T_{\mathrm{P}}\left(\epsilon_{\mathrm{P}}^{\prime}-\epsilon_{\mathrm{P}}\right)+\frac{1}{2} M_{\mathrm{P}}\left(\kappa_{\mathrm{P}}^{\prime}-\kappa_{\mathrm{P}}\right)
$$

膜力・膜モーメントは内圧に比例, 歪・曲率も内圧に比例す るためであるが，このことから将来高圧型の気蓄器を設計 する際には, 圧力にほほ比例して増加する歪ではなく, 口 金剝離の臨界エネルギ解放率が評定になり得ることが容易 に推測される。

この事実を別の側面から見た場合, 強度評定で歪を一定 として設計すると高い内圧に対しては板厚を増やす必要が あり，このためエネルギ解放率増加を招いている（式 (1) に打いて, 膜力 $=$ 弾性率 $\times$ 歪 $\times$ 板厚, 膜モーメント $=$ 曲 げ剛性 $\times$ 曲率 $\times$ 板厚であるため) という見方もできる。こ れは破壊力学におけるスケール効果（エネルギ解放率に長 さの次元が含まれており, 長さの絶対值が効いてくる）の 作用である. 将来のタンク大型化を考えた場合には, 板厚 
は半径に比例して増加させる必要があるため, 大型タンク においても同様に常温でも口金部の剝離が評定となり得る ことが予想される.

本論文では，ロケット搭載用に検討した常温高圧気蓄器 を題材として常温でも口元部接着剥離が設計評定になり得 る例を示し，その対策と効果について議論する。特に比較 的簡単なスリット加工を口金に施工することによって口金 部でのエネルギ解放率を 1 桁程度低減する手法を提案し, またその効果について数值計算を用いて評価する.

\section{2. タンクロ元部接着剝離の問題点}

第 1 図に本論文で計算対象例とするタンクの概要を示す. タンクはロケット搭載用気蓄器として検討した樹脂ライナー 付複合材タンクであるが, 文献 2), 9) 中のタンクと異なり, Filament Winding（FW）製法に対応するため若干の変更 が加えられている。主な変更点は,

・ FW 製法に対応するため, ライナーと CFRP (FW) 層 との間にハンドレイアップによる GFRP 補強層を持つ ・ 口金中央部が円筒状に立ち上げられており, その箇所に FW が巻き付けられている

の 2 点である。補強用 GFRP 層はタンクの胴部から鏡部

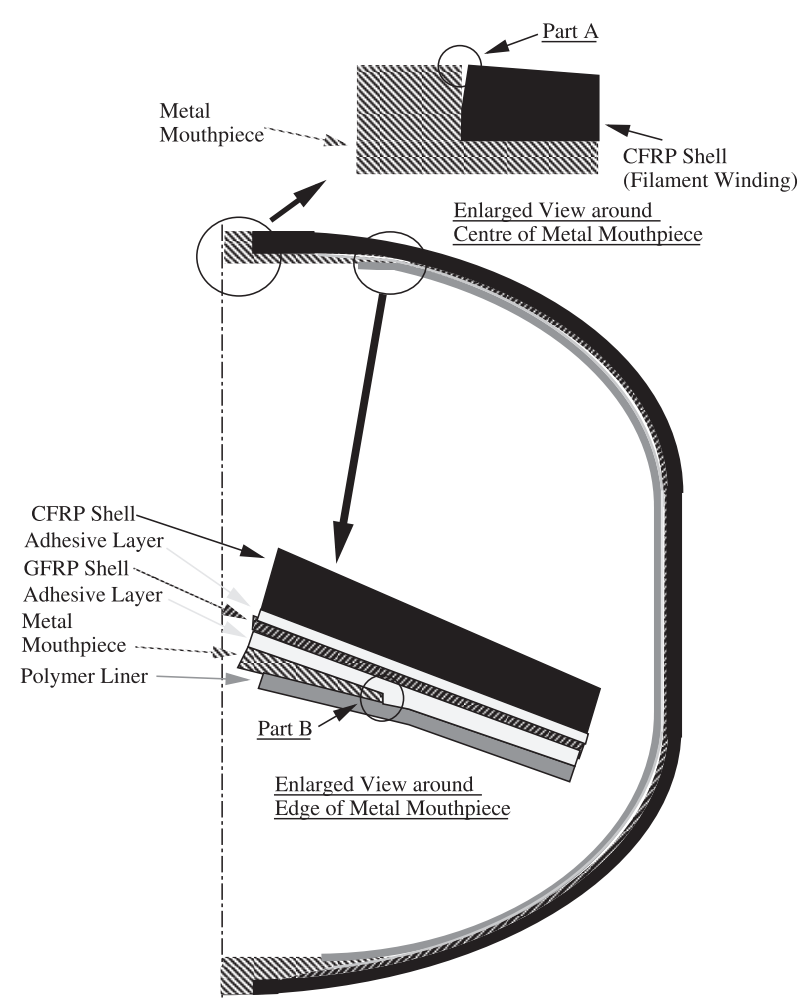

第 1 図 $\mathrm{FW}$ 対応型樹脂ライナータンク概要図

第 1 表 タンク諸元一覧

\begin{tabular}{lc}
\hline Diameter & $700 \mathrm{~mm}$ \\
Length & $1200 \mathrm{~mm}$ \\
Maximum expected operation pressure (MEOP) & $32 \mathrm{MPa}$ \\
Proof pressure & $40 \mathrm{MPa}$ \\
Burst pressure & $48 \mathrm{MPa}$ \\
\hline
\end{tabular}

にかけて積層されており, 口金の途中までを覆っている. GFRP はフィルム接着剤を用いてライナー及び CFRP 層 と接着されている。 GFRPで覆われていない口金部及び口 金中央の円筒部についてはプリプレグからしみたした樹脂 で接着されている。これ以外の製法は文献 2), 9) に示され るタンクと同一である。第 1 表にタンクの諸元を示す.

この形態のタンクにおいては, 文献 9$)$ に記述されている 通り第 1 図中 B で示される口金の外側端部も接着剝離・破 壊の起点となり得るが, この箇所については口金を薄く加 工することにより亀裂進展のエネルギ解放率を低減するこ とが可能である。実際に筆者らが開発した実験機用の複合 材液体水素タンクはこの箇所の板厚を可能な限り薄くする ように設計・製造されている3,4).

一方で第 1 図中 A で示されている箇所における接着界面 でエネルギ解放率が高くなり，この箇所が接着剥離・破壊 の起点となる可能性がある。これは樹脂ライナータンクに 限らず, 一般の金属ライナー複合材タンクにも共通の問題 であり, 現に文献 1) に示されているタンクの開発中にもこ の箇所から剝離が進展し，ライナーの破断に至った経緯が ある. 以下この箇所のエネルギ解放率に着目して計算・考 察を実施する.

\section{3. スリットによるエネルギ解放率低減化}

本論文では，前述のタンク口元部におけるエネルギ解放 率を低減するために，簡単に施工可能なスリット加工を提 案する。これは金属口金・CFRP 接着界面近傍で口金にス リット加工を施すことにより金属口金の剛性を低下させ, 接 着部における応力を緩和し, 接着部予亀裂先端におけるエ ネルギ解放率を低減しようとするものである.

スリットによるエネルギ解放率低減効果の定量的目安を 得るために，本節では第 2 図に示すようなタンク口元部を簡 略化したモデルを用いて考察を行う。このモデルは金属円盤 の外周に複合材を接着した円盤であり, 金属部直径 $50 \mathrm{~mm}$, 複合材部外径 $100 \mathrm{~mm}$, 厚さ $30 \mathrm{~mm}$, 金属部と複合材部界 面に沿って円周状に深さ $L_{0}$ の予亀裂が入っている。この予 亀裂以外の内在欠陥は界面に存在しないとする。 スリット 加工を行う場合は，金属部の外周端から $t$ の位置にスリッ 卜外周端が来るように, 深さ $l$ ・幅 $W$ の円周状のスリット 加工を行う，材質は金属部はチタン，複合材部は周方向が 繊維方向の CFRP であり, 物性值は第 2 表に示す通りで ある. 複合材の外周にはタンク内圧負荷を模擬するために, 半径方向に $100 \mathrm{MPa}$ の一様引張が作用している.

このモデルに基づき有限要素法（FEM）を用いて予亀裂 先端でのエネルギ解放率を求めた。 モデルは軸対称ソリッ ド要素を用いて構成し，エネルギ解放率の計算には FEM ソフトABAQUS 6.6-1 に装備されている J 積分法ルーチ ン10)を使用した。なお FEM における J 積分法の使用は, 数值計算を用いて周回積分の值を計算するため, 経路の取 り方により結果がばらつきを示す。このため, 本論文では 5 経路分の計算を行い, 結果のばらつきから収束性を判断 した．計算結果の一例として， $L_{0}=2 \mathrm{~mm}, t=1 \mathrm{~mm}$, 


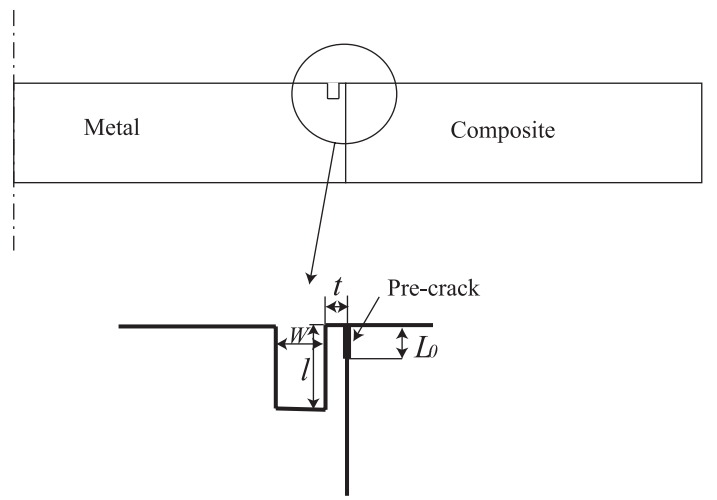

第 2 図 円盤モデル

第 2 表 円盤材料物性

\begin{tabular}{|c|c|c|c|}
\hline & 箇所 & 材質 & $\begin{array}{l}\text { ヤング率 } \\
E(\mathrm{GPa})\end{array}$ \\
\hline FW 複合材 & （繊維方向） & CFRP & 174 \\
\hline $\mathrm{FW}$ 複合材 & （繊維直交方向） & CFRP & 10.0 \\
\hline 口金 & & Ti-6Al-4 V & 115.6 \\
\hline
\end{tabular}

品

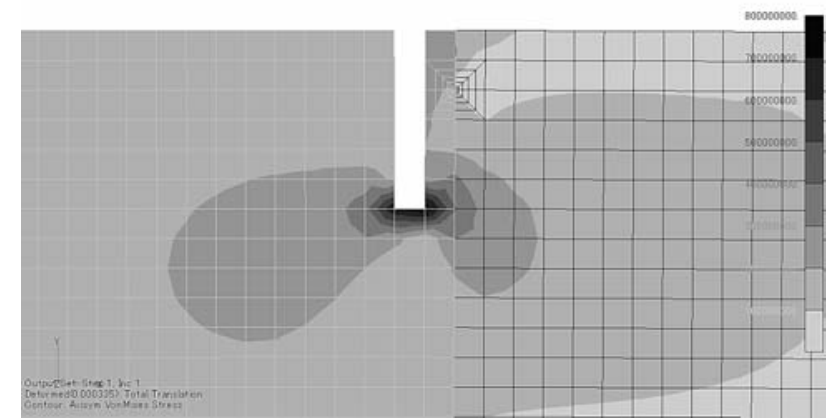

第 3 図 有限要素メッシュとスリット周りの応力分布

$W=1 \mathrm{~mm}, l=6 \mathrm{~mm}$ に対応するスリット周りの有限要 素法の計算メッシュと von Mises 応力の計算結果を第 3 図 に示す.

予亀裂長さ $L_{0}$, スリット〜予亀裂間距離 $t$, スリット幅 $W$ をパラメータとし，スリットの深さ $l$ を $L_{0}$ で無次元 化した值を横軸に，その時の 5 経路分のエネルギ解放率の 平均值 $J$ をスリットがない場合のエネルギ解放率の平均值 $J_{0}$ で無次元化した值を縦軸に取ったグラフを第 4 図に示 す. エネルギ解放率は圧力負荷模擬荷重の自乗に比例する ため, 上記 $100 \mathrm{MPa}$ という境界条件は無次元化を行う上で 計算精度上充分な值である限りは問題にならない.

第 4 図を見ると, 予亀裂と同程度の深さのスリットを入 れた場合のエネルギ解放率の比 $J / J_{0}$ は 8 割前後, 予亀裂 の倍程度の場合は 1 割 2 割程度, 予亀裂の 3 倍以上のス リット深さにすると 1 割以下となることが分かる。 スリッ 卜を更に深く入れることにより，更なる低減効果が得られ ると予想されるが, 今回のモデルではスリット長さがモデ ル厚さの半分近くとなり, それによる応力増加の影響も無

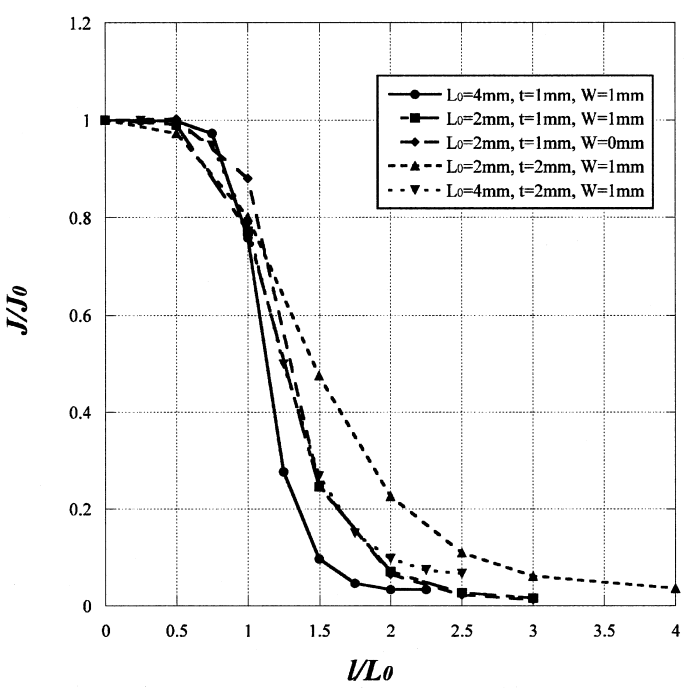

第 4 図 スリット長さとエネルギ解放率の関係

視できないと予想されるため, 今回の計算はスリット深さ は予亀裂長さの 4 倍程度までに留めている。またスリット 〜予亀裂間距離 $t$ に関しては, $l / L_{0}$ が小さい領域では例外 はあるものの, $l / L_{0}>2$ の領域では, $t$ の值が小さい方が よりエネルギ解放率の值が小さくなっていることが分かる.

このことから, 予想される最大予亀裂長さの 2 倍から 3 倍以上のスリットを界面付近に加工することにより，界面 に発生するエネルギ解放率を効果的に低減することが可能 であると言える。

また実際の適用にあたってはスリット先端付近の応力が 材料強度を超えないよう配慮が必要である。例えば第 3 図 を見ると, 最大で $800 \mathrm{MPa}$ (境界条件の 8 倍）程度の応力 がスリット先端付近で発生している。これはこの計算では 要素の削除によりスリットを表現しているため, スリット 先端が角を持つ形状でその応力集中の影響を大きく受けて いるためである。これはスリット先端を R 加工することで 軽減されると予想される。ただし仮にスリット先端を完全 に半円に加工したとしても, 円孔周りの応力分布から類推 すると最大で境界条件の 3 倍程度の応力が半円部先端で発 生すると予想されるため, 注意が必要である. 材料強度を 念頭に置いたスリット先端の $\mathrm{R}$ 加工とスリット〜予亀裂間 距離の設定は今後の研究課題である.

\section{4. タンクモデルによる検証}

本節では，2 節で述べた実際のタンク設計において口金 部の剝離が設計の評定となり，それに対してスリット加工 を行うことにより設計を成立させることが可能となった例 を示す。

4.1 解析モデル 第 5 図に解析を行ったタンクのメッ シュを示す。タンクは気蓄器を想定しており, 計算の簡略 化のため赤道を対称面とした対称形状として計算を行って いる。第 5 図はタンクの半分の軸対称モデルである.

第 5 図中口元部拡大図でメッシュのラインが黒色で要素 


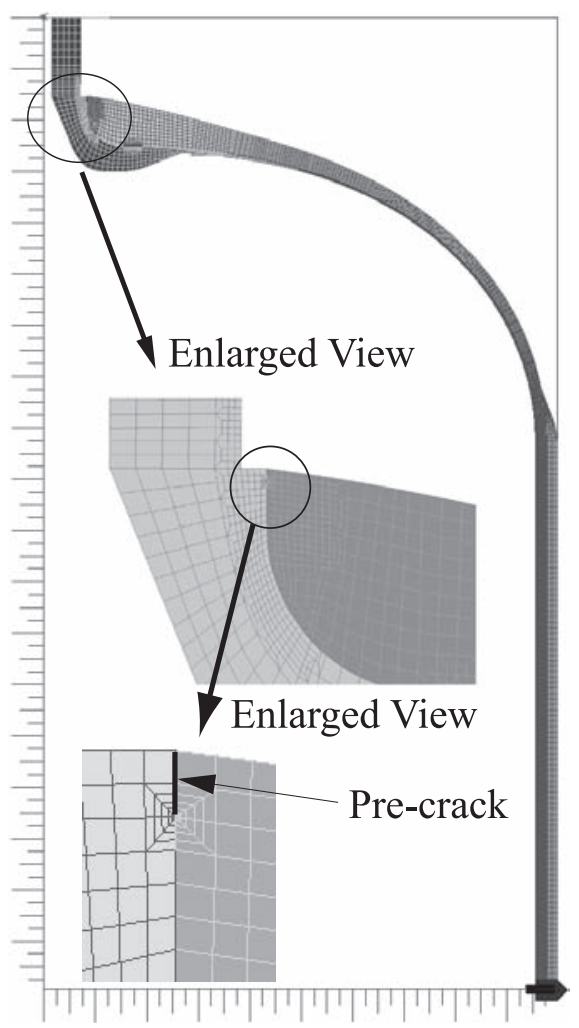

第 5 図 計算対象タンクメッシュ

の色が薄い箇所は口金部でありチタンで作られている。一 方メッシュラインが白色で要素の色が濃い箇所は CFRP 製 である，前節で触れた GFRPによる補強層は口金端部近傍 から始まっており, 図中拡大部には含まれていない.CFRP 部は FW 製法で作られており, 繊維配向によって物性が異 なっているが，製造技術のノウハウに関わる部分もあるた めこの論文では詳細な記述を行わない.

高圧の夕ンクであることから，破壊圧においては口金部 では塑性変形を許容するものとして設計を行っている，材 料の弾塑性挙動は Bi-Linear モデルを用いてモデル化して おり, von Mises 応力が $910 \mathrm{MPa}$ を越えるとヤング率が $12.3 \mathrm{GPa}$ （弾性域の約 $1 / 10$ 程度）となるとした。またバ ウシンガー効果については移動硬化則を用いてモデル化し ている.

計算に使用した物性を第 3 表に示す。なお厳密には GFRP，ライナーは異方性を持っており，面内は疑似等方 であるが厚さ方向には物性が異なる。しかし双方とも剛性 は低く厚さも薄いため, 計算全体への影響は小さいとして 等方性として扱っている。 また前節で述べたフィルム接着 剤を用いて接着を行っている箇所については，接着層をモ デル化している。

タンク口元部のチタン・CFRP 界面に沿って第 5 図に示 す位置に予亀裂を入れ，亀裂先端付近ではメッシュの細分 化を行った。予亀裂の長さは, 非破壊検査による検出能力 と計算メッシュの大きさとを勘案し長さ $2 \mathrm{~mm}$ 程度として いる。 また亀裂面には接触定義がされており，互いの食い
第 3 表 タンク材料物性

\begin{tabular}{|c|c|c|}
\hline 箇所 & 材質 & $\begin{array}{l}\text { ヤング率 } \\
E(\mathrm{GPa})\end{array}$ \\
\hline 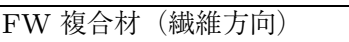 & CFRP & 174 \\
\hline FW 複合材（繊維直交方向） & CFRP & 10.0 \\
\hline 口金 & Ti-6Al-4 V & 115.6 \\
\hline 口金（塑性域） & Ti-6Al-4 V & 12.3 \\
\hline 補強層（疑似等方） & GFRP & 20.7 \\
\hline ライナー & 液晶ポリマー & 4.0 \\
\hline フィルム接着剤 & $\mathrm{AF}-163-2 \mathrm{~K}$ & 1.5 \\
\hline
\end{tabular}

\begin{tabular}{ccc} 
第 4 表 & \multicolumn{2}{c}{ エルギ解放率の計算結果 $\left(\mathrm{J} / \mathrm{m}^{2}\right)$} \\
\hline Path & スリット無 & スリット有 \\
\hline 1 & 28400 & 954 \\
2 & 31200 & 959 \\
3 & 31700 & 961 \\
4 & 31800 & 961 \\
5 & 31800 & 959 \\
\hline Average & 31000 & 959 \\
\hline
\end{tabular}

达みは発生しないようになっている

4.2 解析結果 このモデルを用いて破壊圧 (48 MPa) の条件で亀裂先端のエネルギ解放率を求めた。第 4 表（ス リット無）に口元部のエネルギ解放率の計算結果を示す。エ ネルギ解放率の計算結果は $30000 \mathrm{~J} / \mathrm{m}^{2}$ 前後の值であり, 接 着法にも依存するが常温でのチタン/CFRP (FW) 界面の 臨界エネルギ解放率の推定值 $1420 \mathrm{~J} / \mathrm{m}^{2 * 4}$ を大幅に上回っ ている。予亀裂長さを増大させて計算を行うとエネルギ解 放率は増加していくため, この箇所は $2 \mathrm{~mm}$ 程度の予亀裂 が存在した場合, 亀裂が進展していく状態にある.

一方で塑性歪を含む von Mises 歪の計算結果を歪の大き い口元部を拡大して第 6 図に示す。この計算結果は予亀裂 が入った状態のものであり，特に図中に示す亀裂周辺部で 応力集中が発生し，高い歪が見られている。この箇所につ いては CFRP，チタンとも予亀裂先端付近で局所的に破断 歪を越える值も出てはいるが, これは予亀裂の影響であり, 破壊力学的に評価されるべき箇所であるため, この局所的 な歪は強度上問題ないと考えられる。

また複合材層中に縞状に歪の高い領域が現れているが, これは FEM でモデル化する際に CFRP の材料物性が離散 的となり, その変化の界面で発生している. これに関して は, 更なる要素の細分化・材料物性の変化の平滑化で解決で きる問題であると考えられるが，現実のタンクでは FW 緎 維配向は連続的に変化してこのような現象は発生しないこ と，また計算上発生している歪も 3〜 4\%程度で FW の破断

\footnotetext{
*4 文献 11) ではチタン/CFRP (layup)/チタンの DCB 試験によ る臨界エネルギ解放率は $560 \mathrm{~J} / \mathrm{m}^{2}$ である。この時の CFRP は ハンドレイアップ積層であり, 破壊モードは CFRP の層間剝離 である。対して一般に $\mathrm{FW}$ 製法ではレイアップより層間強度が 高く, 層間の臨界エネルギ解放率も上記より向上し, チタンとの 接着界面の臨界エネルギ解放率は接着層の勒性で決まる值となる と考えられる。チタン/チタンの DCB 試験片では接着層内の凝 集破壊により亀裂が進展しており，チタン/CFRP (FW) 界面の 臨界エネルギ解放率もチタン/チタンの場合と同等の $1420 \mathrm{~J} / \mathrm{m}^{2}$ 程度になると推測される。
} 


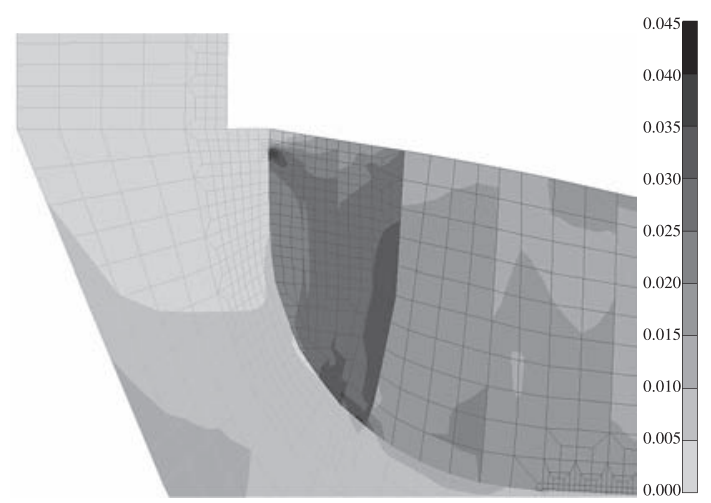

第6図 von Mises 歪分布（スリット無）

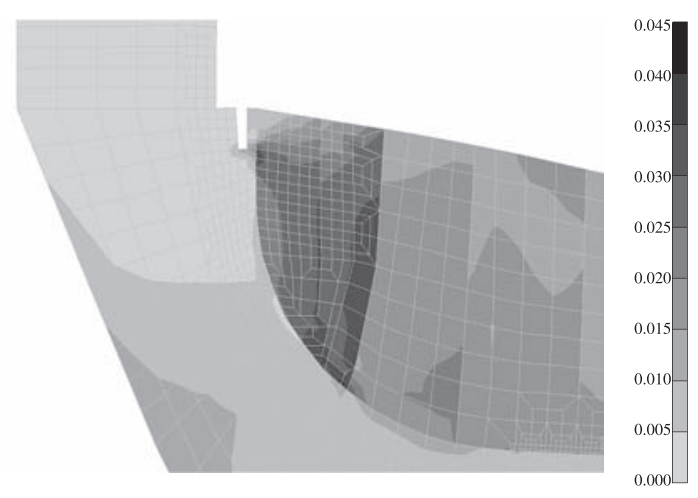

第7図ｖon Mises 歪分布（スリット有）
歪としては許容值程度であることから, 強度上の問題はな い. なお一般部の CFRP の歪の最大值は赤道部で $1.2 \%$ 程 度となって扔り，充分許容できる值である。

口金部のチタンについては, 予亀裂先端部付近を除いて も一部で塑性域に入っており, $1 \%$ 程度の塑性歪が発生して いるが, これは特に問題のない值である.

つまり口金・複合材層ともに歪は許容範囲であり, 強度 的には問題がないと言える。これは即ち, このタンク設計 に扔いては, 破壊圧付近では口元部から接着剝離が進行し ていく可能性が高いことを示しており, 大型・高圧の気蓄 器設計においてはたとえ常温のタンクであっても破壊力学 的な視点が重要であることを示している.

4.3 スリットによるエネルギ解放率低減上記の問題 を解決するため, 金属口金に 3 節で提案したスリット加工 を実施する，前節の解析で使用したモデルに，予亀裂から 約 $1 \mathrm{~mm}$ の位置に深さ約 $4 \mathrm{~mm}$, 幅約 $1 \mathrm{~mm}$ のスリット加 工を施す。これにより金属・複合材の接着部において金属 口金の剛性が低下するため，この箇所でのエネルギ解放率 低減の効果が期待できる. 第 7 図にスリット加工後のモデ ル及び破壞圧に扔ける塑性歪を含む von Mises 歪の分布を 示す．第 7 図では要素の削除によりスリットを表現してい るため, スリットは角を持っているが, 実際の加工におい ては応力集中を軽減するため, スリット先端部は R 加工を 行うべきである。

第 4 表（スリット有）にスリット加工を施した場合のエ ネルギ解放率の計算結果を示す，表を見るとエネルギ解放 率が 1 桁以上改善されており, FW/チタンの接着界面の臨 界エネルギ解放率がチタン/チタンと同程度であれば設計が 成立している。 またこの計算は軸対称モデルを用いている ため円周状に入った亀裂を前提として㧍り, 実際の楕円状 亀裂に対しては亀裂先端のエネルギ解放率が低減されるこ とを考えると，更に余裕を持っている。

また強度については，第 7 図の傾向はほぼ第 6 図と同じ である. 相違点としてスリット先端付近で大きな歪が発生 しているが，これは前述の角のために応力集中が発生して いるためであり， R 加工により解決される. 現在のメッシュ でも歪は $2 \sim 3 \%$ 程度であり, 塑性歪で $1 \sim 2 \%$ 程度であるの
で, チタンでは問題ない程度の值である。

上記の結果は強度的にも勒性的にもタンクの設計上問題 ないことを示している，すなわち，スリット加工を施すこ とにより, 従来では不可能であったタンクの設計を成立さ せることが可能になったと言える。

4.4 タンク計算結果に対する考察 前節で計算した夕 ンクに対するスリットの効果について考察を行う。この計 算モデルの場合，打抢よそ $L_{0}=2 \mathrm{~mm}, t=1 \mathrm{~mm}, W=$ $1 \mathrm{~mm}, l=4 \mathrm{~mm}$ に相当する。第 4 図では同パラメータに 対する值は $J / J_{0}=0.07$ である。 一方で実際のタンクの計 算結果であるが，第 4 表から分かる通り， $J / J_{0}=0.03$ 程 度であり，上記より若干小さい值ではあるがほぼ一致する 結果となっている.

即ち実際のタンクに対しても, 円盤モデルと同様に, 予 想される最大予亀裂長さの 2 倍以上のスリットを界面付近 に加工することにより, 界面に発生するエネルギ解放率を 効果的に低減することが可能であると言える。

\section{5. 結論}

複合材タンク口金部周辺の接着構造において, 将来タン クの大型化・高圧化に伴って予想される口金部接着剝離を防 ぐために，比較的容易に施工可能であるスリットによるエ ネルギ解放率低減化手法を提案した。またスリット形状を 変化させた数值計算によりスリットの効果を定量的に確認 し，実例としてタンクへの適用結果をも示した。な打本論 文は複合材タンクの将来的な大型化・高圧化に扔いて遭遇 し得る問題点の警告と, 比較的容易な技術的解決策を提示 した速報的な論文であり，更に多様なパラメー夕範囲に扔 けるスリットの効果や実験による有効性の裏付け等, 様々 な課題を残している。 今後それらの課題を解決していく予 定である。

\section{参 考 文 献}

1) Higuchi, K., Takeuchi, S., Sato, E., Naruo, Y., Inatani, Y., Namiki, F., Tanaka, K. and Watabe, Y.: Development and Flight Test of Metal-Lined CFRP Cryogenic Tank for Reusable Rocket, Acta Astronautica, 57 (2005), pp. 432437.

2) Sato, E., Arakawa, Y., Higuchi, K., Inatani, Y., Matsuoka, 
S., Naruo, Y. and Takeuchi, S.: Development of Cryogenic Composite Tank Lined with Polymer Film, 56th International Astronautical Congress IAC-05-D2.5.05, 2005.

3) Takeuchi, S., Sato, E., Onoda, J., Naruo, Y., Nonaka, S. and Arakawa, Y.: Design and Development of Cryogenic Composite Tank Based on Fracture Mechanics, 26th International Symposium on Space Technology and Science ISTS2008-c-18, 2008.

4) Takeuchi, S., Sato, E., Naruo, Y., Nonaka, S., Arakawa, Y. and Miyahara, A.: Design and Development of PolymerLined Composite Tank for Liquid Hydrogen Tank of Reusable Vehicle Test, 59th International Astronautical Congress IAC08-C2.1.5, 2008.

5) NASA: Composites for Cryotank Structures. Present and Future: MSFC Perspective, George C. Marshall Space Flight Center, NASA Report, 1996.

6) NASA: Final Report of the X-33 Liquid Hydrogen Tank Test Investigation Team, George C. Marshall Space Flight Center,
NASA Report, 2000.

7) Benton, J., Ballinger, I., Ferretti, A. and Ierardo, N.: Design and Manufacture of a High Performance, High Mass Efficient Gas Tank for the VEGA AVUM, AIAA Paper 20075500, 43rd AIAA/ASME/SAE/ASEE Joint Propulsion Conference, 2007.

8) http://www.lincolncomposites.com

9) Takeuchi, S., Sato, E., Onoda, J., Higuchi, K. and Arakawa, Y.: Evaluation of Adhesive Bonding Structure in Cryogenic Composite Tank Based on Fracture Mechanics, Trans. Jpn. Soc. Aeronaut. Space Sci., 52 (2009), pp. 36-46.

10) Shih, C. F., Moran, B. and Nakamura, T.: Energy Release Rate along a Three-Dimensional Crack Front in a Thermal Stressed Body, Int. J. Fracture, 30 (1986), pp. 79-102.

11）磯崎大樹，中村伊織，宮原 啓，筧 幸次，佐藤英一：極低温複 合材タンク接着構造のモード I/II 破壊挙動, 2009 年度宇宙構造 材料シンポジウム, 2009 . 